УДК 101:2 - 722.5

DOI: 10.37026/2520-6427-2020-103-3-13-16

\section{Олександр ЦІСАР,}

аспірант Національного Університету

«Острозька академія»,

благочинний ПЦУ Кам'янеиь-Подільського району, настоятель Петропавлівської иеркви ум. Кам'янеиь-Подільському, митрофорний протоієрей

\title{
СВІТОГЛЯДНА ПОЗИЦІЯ І. ГІЗЕЛЯ У ДУХОВНІЙ ДІЯЛЬНОСТІ ХVІІ СТОЛІТТЯ
}

У статті представлено світоглядну позицію I. Гізеля через призму його духовної діяльності у XVII cmолітті. Окреслено моральне вчення, релігійне пізнання, антропологічну концепиію людини та ї̈ особистості, а також тісний взаємозв'язок пізнання, поглядів, коничепиій поведінки. Доведено, щчо ідеї цивільного гуманізму, суспільного життя, вільна праия є сенсом життя людини, а свобода-вагомим критерієм у формуванні та розвитку ї̈ здібностей та діяльності.

Ключові слова: «створена природа», розум, інтелект, чуттєве пізнання, матерія, субстаниія, мораль.

В статье представлена мировоззренческая позиичя И. Гизеля через призму его духовной деятельности в XVII веке. Определены нравственное учение, религиозное познание, антропологическая конщепщия человека и его личности, а также тесная взаимосвязь познания, взглядов, концепций поведения. Доказано, что идеи гражданского гуманизма, общественной жизни, свободный труд является смыслом жизни человека, а свобода - весомым критерием в формировании и развитии его способностей и деятельности.

Ключевые слова: «создана природа», ум, интеллект, чувственное познание, материя, субстаниия, мораль.

The significance and role of I. Gizel's worldview position through the prism of his activity are analyzed. The purpose of the article is to determine the main worldview positions, principles that are formed in accordance with his activities. The formation and meaning of cognition, its types, the role of self-knowledge through the prism of achieving goals and objectives are analyzed.

Moral doctrine, religious knowledge, anthropological concept of man, personality and his/her facets are considered. The article analyzes the close relationship between knowledge, views, concepts of human behavior.

In his anthropological concept I. Gizel glorifies man, his dignity and greatness, notes the possibility of infinite perfection. The conscience and mind of man are the criteria of good and evil, govern human actions. The ideal for the thinker was a strong person, educated, free from church prohibitions and restrictions.

Based on the thesis of the rationality of the world, he believes that the truth can be found by considering the consequences of God's activity - «created nature». It can even be argued that Gizel combined Aristotelianism with the ideas of Christian Neoplatonism in his philosophy.
"Created nature» was interpreted by him as a set of ideal beings-universals, a kind of representatives in the world of higher existence. Universals correspond to the existence of their analogues in things. He denied the independent existence of these analogues apart from things. That is, the things themselves cannot exist regardless of the universals.

The philosopher also pays attention to epistemological problems, because knowledge as such plays a signifcant role in shaping the consciousness and principles of human behavior. In particular, sensory cognition and sensory experience play an important role in the formation of prejudices and principles. However, he considered the real source of true knowledge to be a purely intellectual activity, supplemented by moments of intuitive comprehension.

I. Gizel argues that intellectual cognition is a purposeful activity of the subject whose purpose is to obtain practical knowledge (knowledge system or science of the object as a subject of intellectual cognition) and which is carried out through three basic intellectual operations: the formation of concepts, judgments and inference.

Conclusions can be formed as follows: the ideas of civil humanism, social life, free labor are the meaning of human life. Freedom is an important criterion in the formation and development of human abilities and activities.

Key words: "created nature», mind, intellect, sensory cognition, matter, substance, morality.

Постановка проблеми. Інокентій Гізель - одна 3 найосвіченіших постатей в Україні XVII століття, активний учасник публічних диспутів 3 опонентами-католиками, автор низки філософсько-богословських праць, серед яких - «Твір про всю філософію» (1645-1647), «Мир з Богом чоловіку» (1669), полемічного трактату «Правдива віра» (1668), співавтор «Києво-Печерського патерика» (1661). До речі, йому також приписують авторство «Синопсиса» - першого нарису історії України.

Крім того, I. Гізель був одним із перших ректорів школи при Гощанському монастирі, керуючим Печерською друкарнею, архімадритом Києво-Печерської лаври професором, а згодом (починаючи із 1646 р.) і ректором Києво-Могилянської колегії, де читав курси філософії, психології тощо. Така багатогранна діяльність неабияк вплинула на світоглядну позицію філософа та богослова.

Актуальність даної теми полягає в тому, що постать мислителя в сучасній інтерпретації набуває 
нового амплуа, оскільки нинішні дослідження сучасників «воскрешають» міркування Гізеля, наближаючи нас до епохи, в якій жив та працював учений, намагаючись при цьому сучасним поглядом реконструювати історико-філософські та культурно-історичні основи формування його філософських та теологічних поглядів.

Аналіз наукових досліджень і публікацій. Філософська спадщина діячів Києво-Могилянської академії $є$ предметом дослідження значної кількості науковців (В. Горський, Д. Зайцев, П. Кралюк, В. Литвинов, В. Стеценко, І. Шевченко та ін.).

Дослідженню творчості І. Гізеля присвячено розвідки Н. Прядко, Я. Угляра. Його релігійно-етичний трактат «Мир з Богом чоловіку», в якому автор окреслює низку філософських, психологічних та педагогічних проблем, аналізують Л. Довга, О. Матласевич, Г. Наєнко. Унікальними в цьому контексті $є$ й дослідження М. Корзо про авторство православних текстів.

Мета статті - схарактеризувати основні світоглядні позиції та принципи, сформовані І. Гізелем у духовній діяльності XVII ст.; проаналізувати значення пізнання та самопізнання, його види та роль через призму досягнення цілей та мети діяльності.

Виклад основного матеріалу. Одним із представників пізнього гуманізму та раннього Просвітництва XVII ст. є Інокентій Гізель (? - 1683), викладач філософії Києво-Могилянської академії, філософ, мислитель та впливовий церковний діяч. До наших днів дійшов філософський курс, який він читав в академії, а також низка інших творів, які були відомі навіть у православних монастирях Османської імперії.

Роздумуючи над світоглядними поглядами Гізеля, варто відзначити, що під час написання своїх праць він використовував античну спадщину, твори отців церкви, середньовічних схоластів, представників неосхоластики, новочасних авторів (Д. Кардано, Г. Галілея та ін.), а також перший серед філософів Києво-Могилянської академії згадав про геліоцентричну теорію Коперника.

Гізель як надзвичайно освічена і талановита особистість був небайдужий до всього, що відбувалося у світському і релігійному житті тогочасної України, розумів складність і суперечність сучасної йому дійсності. Водночас на рівні філософських узагальнень особливу увагу він звертає на значущість адекватного пізнання людиною самої себе та свого існування. Роздуми філософа над таємницями психіки призвели до виокремлення ним п'яти потенцій людської душі, зокрема плотської й розумної. Знання про навколишній світ, на переконання мислителя, мають меншу цінність, аніж знання індивіда про самого себе. Самопізнання безмежне. Воно, з одного боку, є необхідною умовою пізнання світу, розкриття єдності мікро- та макрокосмосу, а з іншого - шляхом наближення людини до Бога, відшукування Бога в людській душі. Ідею про те, що «...Бог є найвищою з усієї суті та останньою метою» [1, с. 290], Гізель у різних варіаціях послідовно проводить через усі свої праці. У своїй антропологічній концепції він звеличує людину, іiі гідність і велич, відзначає можливість безмежної досконалості. Совість і розум людини, на його думку, - це не тільки критерії добра і зла, а й те, що керує людськими вчинками. Ідеалом для мислителя була сильна особа, вільна від церковних заборон і обмежень.

Гізеля можна назвати «патріотом Києво-Печерської лаври». Справді, завдяки його старанням монастир зберіг свій ставропігійний статус, тобто безпосереднє підпорядкування Константинопольському патріархату, і залишався одним із головних релігійно-культурних осередків у православному ареалі Східної Свропи. Більше того, цей осередок і надалі розвивався. Так, Гізель тут створив гурток інтелектуалів, які готували до друку книги. Сама ж друкарня монастиря перетворилася у потужний видавничий центр, продукція якого поширювалася не лише в Україні, а й далеко за ії межами.

У 1656-1683 роках, коли Гізель був архімандритом Києво-Печерської лаври, у їі друкарні побачили світ щонайменше 77 видань, зокрема: 2 букварі; 11 авторських богословських текстів; 8 авторських збірників проповідей; 3 поетичні збірки авторства Лазаря Барановича; 4 видання «Синопсису»; 1 царська грамота; 2 видання Києво-Печерського патерика; 6 невеликих публікацій із житіями святих, передусім київських; 1 перевидання «Тестаменту грецького царя Василія... сину своєму Льву»; 1 Мінея; 4 Требники; 3 Псалтирі; 2 Молитослови; 2 видання Нового Завіту; 1 Апокаліпсис; 9 перевидань Часословів; 5 перевидань Акафісників; 13 видань іншої літератури богослужбового змісту. Як бачимо, переважала тут література літургійного та богословського характеру, що $є$ цілком зрозумілим, однак привертає також увагу значний відсоток авторських текстів, що свідчить про підтримку Гізелем інтелектуального життя у православній Київській митрополії. Він, наприклад, не тільки домігся, щоб книги з Києво-Печерської лаври дозволили продавати в Москві, а й відкрив там першу спеціалізовану книгарню.

Зважаючи на тезу про розумність світу, Гізель переконував, що істину можна осягнути, споглядаючи наслідки Божої діяльності зі «створення природи». У цьому його погляди були співзвучними з поглядами українських мислителів попередніх часів. Можна навіть стверджувати, що Гізель у своїй філософії поєднував аристотелізм з ідеями християнського неоплатонізму. «Створена природа» трактувалася ним як сукупність ідеальних сутностей-універсалій - своєрідних репрезентантів у світі вищого буття. Так, універсаліям відповідає існування їхніх аналогів у речах, а самостійне існування цих аналогів окремо від речей заперечується, тобто самі речі, незалежно від універсаліїв, існувати не можуть.

Філософ також значну увагу приділяє і гносеологічним проблемам, адже пізнання відіграє вагому роль у формуванні свідомості та принципів поведінки людини, зокрема чуттєве пізнання та чуттєвий досвід сприяють формуванню упереджень та принципів. Однак, на його думку, справжнім джерелом істинного пізнання $є$ інтелектуальна діяльність, що доповнюється моментами інтуїтивного осягнення [2, с. 247].

Перевірка істинного розуміння істотних зв'язків між предметами зовнішнього світу забезпечується такою інтелектуальною операцією, як судження, в якому суть предмета виявляється в розгорнутому вигляді, вираженому у формі речення. Стосовно фантазії, то, на думку Гізеля, вона має відношення до утворення інтелігібельних образів лише як організуюче начало, а пасивний інтелект, отримавши від активного інтелігібельні образи з допомогою дискурсу, добуває з себе самого свої власні, більш абстрактні образи. Ці застереження з'явилися внаслідок концептуалістського трактування Гізелем проблеми універсалій, адже будь-який представник концептуалізму 
був переконаний, що в людському інтелекті зосереджено цілий ряд речей, від яких людина не може утворити пов'язаних із чуттєвим пізнанням уявних образів і які не доступні для чуттєвого пізнання. Водночас під річчю тоді розуміли не тільки щось матеріальне, а й будь-яку ідеальну сутність. До такого типу речей відносили загальні поняття, як-от: роди, види, сукупність ідеальних сутностей речей (щойності), які складають природу, наприклад, Бога, ангелів, тобто весь той ідеальний світ умоосяжних сутностей, що уявлявся філософові істинним буттям і що, на його думку, вдавався до пізнання лише 3 допомогою чистого мислення. Через це діяльність чистого мислення - інтелекту - набуває в Гізеля автономного характеру. Пізнання цього істинного буття, яке він уважав вищою метою філософії, а також пізнання сутностей речей матеріального світу інтелект повинен був здобути від себе самого, позаяк вони (сутності) були його вмістом, знаходилися у ньому, а онтологічні аналоги цих понять містилися в речах навколишнього світу. У зв'язку з цим Гізель переконував, що інтелект лише в тому розумінні $є$ чистою дошкою, на якій ще нічого не написано, коли він ще не визначився щодо об'єкта свого пізнання за допомогою інтелігібельних образів. У процесі пізнання пріоритетного значення він надає не дії зовнішніх об'єктів на органів чуття, а самовизначеності інтелекту щодо цих об'єктів [3, с. 55].

Інтелектуальне пізнання, доводить Гізель, - це цілеспрямована діяльність суб'єкта, метою якого є отримання практичного знання (системи знань, або науки про об'єкт як предмет інтелектуального пізнання) і яке здійснюється за допомогою трьох основних інтелектуальних операцій: утворення понять, суджень й умовисновків. За допомогою означених операцій інтелект утворює єдине загальне поняття, яке $є$ образом істотних ознак, що наявні у предметах незалежно від інтелекту. Особливий наголос при цьому робиться на увазі.

Одним із ключових понять філософії Гізеля було поняття Бога. Мислитель трактує Бога як необхідне та самодостатнє суще. Він є буттям, сутність та існування якого тотожні. Бог - нематеріальний, безсмертний, досконалий, єдиний, всюдисущий. Матерія ж характеризувалася Гізелем як неповна субстанція. Будучи первинним суб'єктом, вона не може містити в собі інший суб'єкт, а потребує доповнення ще однією частиною - формою. Зважаючи на це, матеріальні речі не існують без форми, проте, будучи простою буттєвістю, першоматерія не складається із суб' єкта і форми й не визначається через форму.

У своєму філософському курсі Гізель робить спробу обгрунтувати поняття якості, форми інструментом опису структури самого процесу зміни. Замість форми, яка, на думку Аристотеля, є єдиною й невіддільною від речі, виникає уявлення про ряд форм, із допомогою яких пояснюється процес зміни. Розробка проблеми «інтенсифікації і ремісії форм» призвела не лише до зближення таких несумірних в аристотелівському вченні категорій, як «кількість» та «якість», а й до зближення «матерії» і «форми», що асоціювалися в античній та середньовічній філософії 3 категоріями кількості та якості, а також - до відходу від перипатетичної концепції про незмінність субстанційних форм. Кожна якість, на думку Гізеля, має досягти певного, відповідного своїй природі, найбільш досконалого ступеня, що зумовлений іiі внутрішньою і зовнішньою межею.
Інтенсивність I. Гізель розумів як адитивне зростання, нагромадження градусів (ступенів) якості, що виникало через складання під час процесу інтенсифікації. Ці градуси якості були або гомогенними, або того ж порядку, що й попередні, крім числової. Інтенсивність збільшувалася від однієї точки до іншої, причому Гізель не погоджувався 3 думкою інших учених, що інтенсивність і розосереджування настають унаслідок розкладу попередньої якості й утворення нової, яка в індивідуумі є тією самою за видом, тільки більш або менш досконалою. Збільшення інтенсивності якості відбувалося, на його думку, внаслідок складання (об’єднання) наступної частини якості з попередньою.

Учення про інтенсифікацію і ремісію форм мало неабияке історико-філософське й наукове значення. Пов'язане $з$ прагненням кількісно оцінити й виразити якість, знайти кількісну межу тієї чи іншої якості, воно було першою спробою сформулювати принцип взаємоперетворення кількості в якість.

Таким чином, Гізель репрезентує себе як особу, яка стоїть на позиціях цивільного гуманізму і патріотизму. Його ідеалом є сильна особистість, повновладний господар своєї долі та вчинків. Щоб відчувати себе впевненим у власних силах, мислитель радить багато читати, веселитися, радіти життю, насолоджуватися земними благами, остерігаючись, однак, нерозумного томління плоті. Крім того, він глибоко вірить у силу людського розуму й переконаний, що людина сама, без сторонньої допомоги може протистояти поганим учинкам. Навіть тоді, коли іiі переслідують гнів, бажання помститися та інші недобрі почуття, вона віднайде в собі сили не піддаватися їм, адже володіє розумом та волею [2, с. 249].

Однією із ключових проблем, які Гізель порушує у своїх працях, є проблема людини та ії моралі. Зокрема, філософ обгрунтовує ідеї цивільного гуманізму, закликає до активного суспільного життя, вільної праці, яку вважає сенсом людського життя. Саме вільний вибір праці допомагає людині сформувати свої погляди та життєву позицію. Шлях досягнення земного щастя Гізель пов'язує з ідеями патріотизму і свободи, а основним принципом, якому повинні підкорятися всі правителі, вважає принцип загального блага.

Таким чином, можемо стверджувати про безпосередній зв'язок життєдіяльності Інокентія Гізеля iз його світоглядною позицією. Богослов, філософ, культурний, церковний і суспільний діяч, людина, яка дотримувалася активної громадської позиції, - усе це сформувало ті чи інші погляди на життя загалом.

Висновки. Зважаючи на викладене вище, зазначимо, що І. Гізель ключовою вважав проблему Бога i його ставлення до світу. Розглядаючи іiі, дотримувався деїстичних позицій, близьких до ренесансних, що проявляються у поєднанні та рівноправності матеріального й ідеального моментів у визначенні природи, а також неоплатонівських концептуальних інтерпретацій Бога, який, на думку Гізеля, немає фізичних першооснов, а $є$ сутністю нематеріальною, безкінечною, безмежно досконалою, що пізнається природним розумом.

Світоглядні погляди І. Гізеля становлять інтерес 3 огляду на розв'язання ним проблем сенсу життя, можливості досягнення щастя, взаємозв'язку волі й розуму. Як і інші «могилянці», сенс життя він вбачає у творчій праці, спрямованій на власне й громадське добро. Зважаючи на світоглядні тенденції барокової 
доби, філософ переконує, що проблему взаємозв'язку волі й розуму можна вирішити, дотримуючись концепції етичного інтелектуалізму, а щастя можна досягти шляхом компромісного поєднання задоволення потреб різних складових душі - як тілесних, так і духовних. Визнаючи свободу волі, він надавав пріоритетного значення розуму, який, на його думку, чинить на неї неабиякий моральний вплив.

Подальші дослідження у даному напрямі плануємо спрямувати на обгрунтування основних богословських концепцій I. Гізеля, їхнє тлумачення та потрактування.

\section{СПИСОК ВИКОРИСТАНОЇ ЛІТЕАТУРИ} $666 \mathrm{c}$.

1. Гизель И. Мир с Богом человеку. Киев, 1669.

2. Кралюк П. М. Історія філософії України : навчальний посібник. Острог : НаУОА, 2013. 652 с.

3. Ничик В. Философия в Киевской братской школе. Философская мысль. Киев, 1982. № 2. С. 54-72.
4. Прядко Н. А. Морально-етичні критерії особистості у філософському трактаті І. Гізеля «Мир 3 Богом чоловіку». Вісник Київського національного університету імені Тараса Шевченка. Філософія. Політологія. 2004. № 68/69. С. 36-39.

5. Довга Л. М. Моральні концепції українських інтелектуалів XVII ст.: уявлення про вірність та зраду. URL: http://knmau.com.ua/chasopys/05_NBUV/ web/16 Dovga.pdf (дата звернення: 13.03.2020).

6. $\bar{\epsilon}$ мець Н. Світоглядно-філософські засади української естетичної думки доби бароко. Вісник Національної академії керівних кадрів культури і мистецтв. 2013. № 2. URL: http://visnyknakkkim.in.ua/index.php/ visnyk/article/view/501 (дата звернення: 10.05.2020).

7. Прядко Н. «Громадянський гуманізм» як основний принцип формування суспільно-активної особистості у філософському вченні I. Гізеля. URL: http://dspace.pnpu.edu.ua/bitstream/ (дата звернення: 05.04.2020).

Дата надходження до редакиіï: 17.07.2020 p. 